Study Division organized an international conference at CERN on the theoretical aspects of very-high-energy phenomena during June $5-9,1961$. The proceedings were published as CERN Publication 61-22.

The Film-badge Service of the Health Physies Group monitored 1,069 people for $\gamma$-radiation, and in addition about 140 people were also under neutron film-badge control. Only 78 people received a dose exceeding 1 rem for the year. In seven cases the maximum permissible annual exposure of 5 rems was approached. Arrangements for making blood tests of people exposed to radiation were improved and extended. A monitoring system for all waste leaving the CERN site has been set up. Routine weekly surveys of the radiation-level from the proton synchrotron and from the synchro-cyclotron were made.

Careful consideration was given during the year to the question of the rate of growth of the Organization in the future. The Council agreed on a budget for 1962 which would permit a moderate rate of growth and decided that during 1962 a more profound study should be under. taken by a special working party of the basic questions on which any policy for the future should be founded. Provision was made in the budget for 1962 for an intraEuropean study-group to produce design studies of two possible future projects, a storage ring device to be fed from the present proton synchrotron and $a_{3} 300-\mathrm{GeV}$ highintensity proton synchrotron. The device is likely to consist of two storage rings of the same size as the proton synchrotron, but with d.c. magnets with split focusing and bending. The r.f. system would also be smaller and more delicate. The cost is estimated to be less than twice the cost of the proton synchrotron and the construction time about five to six years.

Because of a serious shortage of staff in the Public Information Office the production of the CERN Courier had to be practically suspended and many other activities were greatly handicapped. Four television programmes and ten radio programmes were arranged. English, French and Italian versions now exist of the CERN film Matter in Question, which was awarded the Grand Prix in its class at the International Festival of technical and scientific films in Budapest. A German version is to follow during 1962. A total of 5,867 people in 206 conducted parties were shown around the establishment, and a new scheme of visits is being worked out to allow visitors still to see as much as possible although the accelerators are now practically inaccessible. The separate report of each Division concludes with a list of publications by members of the Division, and in two appendixes to the annual report are listed the 1961 CERN publications; reprints of publications during 1961 in other periodicals by members of the staff of CERN; and details of the lectures, seminars and colloquia held at CERN.

S. WEINTROUB

\title{
RECENT DEVELOPMENTS IN ASTRONOMIC AND SPECTRONOMIC INSTRUMENTS
}

$\mathrm{W}$ ORK undertaken during 1962 by Sir Howard Grubb Parsons and Co., Ltd., has included a number of interesting and unusual projects. A 48-in. reflecting telescope has been erected at the Victoria Observatory, British Columbia, and a rather uncommon type of telescope, a twin 16-in. reflector, has been manufactured for the Royal Observatory at Edinburgh. Each tube of the twin reflector contains a 16-in. primary mirror and a Cassegrain mirror giving an overall focal ratio of $f / 15$. One of the tubes can be off-set from the other in any direction up to $5^{\circ}$ and simultaneous photometry can be carried out on two stars. The operation of the telescope can be made fully automatic.

Because of difficulty in obtaining acceptable glass blanks for the eomponents of the complex optical system for the 40-in. reflector for the Cape Observatory, the completion of the telescope has been held up. The optical system uses a parabolic mirror and a lens system affording a wide field of good definition at the prime focus. A large correcting plate is located at about the prime focus and a correcting lens is inserted in the beam just before it comes to a focus. When the optical system is assembled it will be necessary to mount it in the telescope tube and test it in the tube. The test will be carried out in the test tower at the works. All the heavy items and fabrications for the 98-in. Isaac Newton reflecting telescope have been received and many of the machining operations have been completed.

Newly developed instruments include the 'Spectromaster', an infra-red spectrometer, covering a wavelength range of $0 \cdot 6-25 \mu$, and an interferometric spectrometer based on the work of Dr. H. A. Gebbie at the National Physical Laboratory. Now techniques have been developed to produce very narrow band interference filters for the visible and selective filters for the infre-red. For the U.K. Atomic Energy Authority establishment at Harwell, two remotely controlled gas analysers to monitor carbon monoxide and carbon dioxide in a helium test loop for Pluto have been made, and four glass windows have been polished for use in a liquid hydrogen bubble chamber. Four oval windows for a similar purpose are to be ground and polished for use by the European Organization for Nuclear Research (CERN). Measuring $70 \times 25 \times 6$ in. and weighing approximately 1,300 lb. each, they will constitute the largest pieces of optical glass ever to be manufactured anywhere in the world.

\section{PAL/EONTOLOGY IN THE U.S.S.R.}

ONSIDERABLE advance has been made in palæon-
tological research in the U.S.S.R. during the past
half-century, following on the great development in this
field of scientific activity in Russia during the nineteenth
century. Characteristic of the present-day approach is the
re-orientation of palæontology so that it is no longer treated
as a mere annex of stratigraphy but is linked more closely
with biology (theory of evolution, ecology, geological
facies and conditions of fossilization). The Palæontological
Society, founded in 1916, has actively sponsored this research and much has been done by the numerous geological institutes and the universities. Publication has been covered by various scientific periodicals, more particularly the four series-Palceontology of the U.S.S.R., Problems of Palceontology, Palceontological Journal and Transactions of the Paloeontological Institute.

The old-type description of fossils, collected by overworked geologists, is replaced by planned systematic work, specially organized to combine field and laboratory investigations. Examples of such work can be seen in 
recent expeditions to investigate a large accumulation of fossil bones of reptiles of Permian age, discovered in 1949 near the village of Eschovo, south of the town of Ochera on the River Kama. The systematic excavation. of this fossil field was begun by members of the Palæontological Institute in 1957 and is still in progress. The results so far obtained are summarized by $\mathrm{P}$. K. Chudinov (Priroda, 4, 78; 1962). The majority of fossils belong to the group of Deinocephalia, genera Estemmensuchus and Eotitanosuchus. The name Ocheria is given to the remains of a new genus. There are also a few remains of Amphibia, such as Melanosaurus. The fauna, as a whole, is considered to be intermediate between those of North American and South Africa. Another important ossuary, discovered by members of the East Siberian Geological Institute in a locality $15 \mathrm{~km}$ south-west of Ulan-Ude Transbaikal region, and reported by L. N. Ivaniev (Priroda, 6, 78; 1962), consists of fossil bones of Tertiary and Quaternary mammals. They include well-preserved remains of Hipparion and other genera belonging to the same faunistic group.

The following is a very brief guide to some of the work covered during the past decade:

Protozoa, especially Foraminifera-by a number of research workers, especially micropalæontologists.

Archaeocyathidae, a group of rather problematic fossils intermediate between corals and sponges, found in the deposits of the Lower and Middle Cambrian, especially in the Asiatic part of the U.S.S.R. A. G. Vologdin (Priroda, 10, 185; 1962) describes a large amount of work on the investigation of this group since the expert summary by A. P. Borisyak (Priroda, 7-9, 315; 1919). More than one thousand species have been described. Colenterata, B. S. Sokolov; Bryozoa, M. I. Shulga-Nesterenko and A. I. Nikiforov; Brachyopoda, Chernyshev et al.; Trilobita, V. V. Weber and E. V. Lermontova; Quadrupeda, P. P. Shushkin; fossil plants, I. M. Pokrovskaya and S. M. Naumova.

The only way of dealing with the abundant palæontological literature published during the past three years is to give the titles of the recent volumes of the Transactions of Palceontological Institute:

80, The Spiriferidae of the Kazan stage of the Russian platform and the conditions of their co-existence, by A. D. Slyusareva $(1960) ; 81$, The Devonian bivalve Phyllopoda, by N. Novozhilov (1961); 82, The late Devonian sea of the Kuznetzk depression, history of its development, population and deposits, by T. N. Bel'skaya (1960); 83, The principles of systematics, system and phylogeny of Palæozoic Ammonoidea, by V. E. RuzhentzeV (1960); 85, Palæozoic insects of Kuznetzk basin, by E. E. Beckerr-Migdasova, O. M. Martynova and A. G. Sharov (1961); 86, Devonian Bryozoa of the Minusinsk and Kuznetzk basins, by I. P. Morozova (1961); 87, Artinskian Ammonoidea of the Middle Urals, by M. F. Bogoslovskaya (1962); 88, Ecology and the development of Silurian and Devonian brachiopoda of the Kuznetzk, Minusinsk and Tuva basins, by E. A. IV̌anova; 89 , Cambrian Algae of the south-eastern part of the Siberian platform, by K. B. Korde (1961); 90, Fundamental problems in the systematics of Nautilidea and related groups, by V. N. D. Shimansky and F. A. Zhuravleva (1961); 91, Saline-water Pliocene Cardiatidae of the U.S.S.R., Part 4, by A. G. Eberzin (1962).

But the most spectacular and certainly the most important publication in the Soviet Union is the projected 15-volume Principles of Palocontology written by two hundred specialists and containing not only accounts of recently discovered fossils in the Soviet Union but also a systematic account of the world's fossils, illustrated by numerous photo-reproductions and line drawings, and accompanied by a critical discussion of their systematics, nomenclature and distribution in space and time.

The titles of the fifteen (non-numbered) volumes of the Principles of Paloeontology (Osnovy Paleontologii) are: General part, Protozoa; Porifera, Archaeocyathidea. Colenterata; Mollusca: Loricata, Bivalva, Scaphopoda Supplement: Vermes; Mollusca: Gastropoda; Mollusca: Cephalopoda. I, Nautiloidea, etc.; Mollusca: Cephalopoda. II, Ammonoidea, etc.; Bryozoa. Brachiopoda, Supplement: Phonoronidea; Arthropoda: Trilobita, Decapoda; Arthropoda: Trachaean, Chelicerata; Echinoderma, Hemichordata; Astomata, Pisces; Amphibia, Reptilia, Aves; Mammalia; Algae, Fungi, Bryophyta, Pteridophyta; Gymnospermae. Angiospermae.

One can get more information by looking at the particulars of the two most recently published volumes in this series:

Bryozoa. Brachiopoda. Suppl.: Phonoridea, edited by T. G. Saryoheva, written by twenty authors. $343 \mathrm{pp}$. 82 plates, 485 text-figs. 1960 . Price $3 \mathrm{r} .82 \mathrm{k}$.

Mammalia, edit. by V. I. Gromova. Written by thirteen authors. 421 pp. 543 text-figs. 1962. Price 2 r. $61 \mathrm{k}$.

The Principles of Paloeontology (Osnovy Paleontologii) is produced by the Palæontological Institute, Moscow Academy of Sciences (Lenin Prospect, 33, Moscow B-71) in collaboration with a number of other institutes.

\section{S. I. TOMKEIETF}

\title{
BIOLOGICAL SIGNALS AND NOISE
}

\author{
BY DR. L. MOLYNEUX \\ Department of Physics, Kings' College (University of Durham), Newcastle upon Tyne
}

T HE word 'noise' in a scientific context is usually used to describe random fluctuations of potential; however, the definition can be usefully expanded to mean extraneous information of the same kind as that which is of interest in a particular situation'. For example, if the biological phenomenon is the movement of some part of the anatomy with respect of its surrounding tissue (say, the pulsation of an artery), then 'noise' will include any movement of the artery with respect to the pick-up device which is not directly due to arterial expansion.

Or again, if the biological signal is the potential difference between two points on the skin (say, the electroencephalogram) then the 'noise' will include any potential difference appearing across the input electrodes, regard- less of whether the source of the disturbance is external (alternating current mains supply) or internal (musclo potentials).

Anyone who has tuned a radio from station to station will have heard between the stations fairly 'white' noise. The expression 'white' here means that the frequency spectrum of the noise is spread over most of the audible band-width, and that it is not concentrated at a particular frequency. It is noticeable that a weak station can be better understood in the presence of 'white' noise than if the interference is coming from another station broadcasting in the same language. This is because, in the case of the interfering station, the 'noise' more closely resembles the signal than do the random background 